Article

\title{
Characteristics of Transformational Adaptation in Climate-Land-Society Interactions
}

\author{
Koko Warner ${ }^{1, *}$, Zinta Zommers ${ }^{2}$, Anita Wreford ${ }^{3}(0)$, Margot Hurlbert ${ }^{4} \oplus$, David Viner ${ }^{5}$, \\ Jill Scantlan ${ }^{2}$, Kenna Halsey ${ }^{6}$, Kevin Halsey ${ }^{6}$ and Chet Tamang ${ }^{2}$ \\ 1 United Nations Climate Change Secretariat, Platz der Vereinte Nationen 1, 53113 Bonn, Germany \\ 2 Mercycorps, 45 SW Ankney St., Portland, OR 97204, USA; zzommers@mercycorps.org (Z.Z.); \\ jscantlan@mercycorps.org (J.S.); ctamang@mercycorps.org (C.T.) \\ 3 Agribusiness and Economics Research Unit, Lincoln University, Ellesmere Jct Rd, \\ Lincoln 7647, New Zealand; Anita.Wreford@lincoln.ac.nz \\ 4 Faculty of Arts, University of Regina, 3737 Wascana Pkwy, Regina, SK S4S 0A2, Canada; \\ margot.hurlbert@uregina.ca \\ 5 Mott MacDonald, 22 Station Rd, Cambridge CB1 2JD, UK; david.viner@me.com \\ 6 EcoMetrix Solutions Group, Polebridge, MO 59928, USA; kenna@ecometrixsolutions.com (K.H.); \\ kevin@ecometrixsolutions.com (K.H.) \\ * Correspondence: kwarner@unfccc.int
}

Received: 7 October 2018; Accepted: 25 December 2018; Published: 11 January 2019

\begin{abstract}
Countries across the world aspire towards climate resilient sustainable development. The interacting processes of climate change, land change, and unprecedented social and technological change pose significant obstacles to these aspirations. The pace, intensity, and scale of these sizeable risks and vulnerabilities affect the central issues in sustainable development: how and where people live and work, access to essential resources and ecosystem services needed to sustain people in given locations, and the social and economic means to improve human wellbeing in the face of disruptions. This paper addresses the question: What are the characteristics of transformational adaptation and development in the context of profound changes in land and climate? To explore this question, this paper contains four case studies: managing storm water runoff related to the conversion of rural land to urban land in Indonesia; using a basket of interventions to manage social impacts of flooding in Nepal; combining a national glacier protection law with water rights management in Argentina; and community-based relocation in response to permafrost thaw and coastal erosion in Alaska. These case studies contribute to understanding characteristics of adaptation which is commensurate to sizeable risks and vulnerabilities to society in changing climate and land systems. Transformational adaptation is often perceived as a major large-scale intervention. In practice, the case studies in this article reveal that transformational adaptation is more likely to involve a bundle of adaptation interventions that are aimed at flexibly adjusting to change rather than reinforcing the status quo in ways of doing things. As a global mosaic, transformational change at a grand scale will occur through an inestimable number of smaller steps to adjust the central elements of human systems proportionate to the changes in climate and land systems. Understanding the characteristics of transformational adaptation will be essential to design and implement adaptation that keeps society in step with reconfiguring climate and land systems as they depart from current states.
\end{abstract}

Keywords: climate change; transformational adaptation; development; risk; climate-land-society interactions; urban flooding; ecosystem service; financial services; glacier; permafrost thaw; managed retreat 


\section{Introduction}

An increasing body of evidence suggests that changes in land cover and land use significantly influence climate. Indeed, climate change combined with land use alterations, and societal shifts are contributing to threats that undermine the basis of human and environmental well-being. This article builds on the transformational adaptation literature to identify new types of approaches undertaken to adjust to risks from emerging land, climate and social interactions. It focuses specifically on approaches undertaken at different scales and approaches implemented in new locations, concluding that transformational outcomes can be achieved through small flexible packages of interventions improving governance.

Humans are influencing earth systems as never before [1,2]. Globally over $75 \%$ of ice-free land has been altered by human activity. For example, fresh water supplies are rapidly diminishing in irrigated agricultural regions [3]. At the same time, human activities are estimated to have caused approximately $1.0^{\circ} \mathrm{C}$ of global warming above pre-industrial levels. Such changes in biophysical and climate systems are driving sea level rise, glacial melt, desertification, land degradation and biodiversity loss. Together with demographic shifts, urbanization, and migration, a new risk landscape is emerging in areas such as human health, food security, livelihoods, and other elements of human well-being [4]. The ecological ranges of diseases such as zika, dengue and chikungunya are changing and likely to expand under climate and land use change [5-8]. Yields of major crops such as maize, wheat and rice are expected to decline by with increasing temperature, jeopardizing food security [9].

Although there is low certainty about thresholds, there is high confidence that tipping points will be reached in climate scenarios exceeding $1.5^{\circ} \mathrm{C}$. Tipping point examples include irreversible melt of the Greenland ice sheet, dieback of the Amazon rainforest and shift of the West African monsoon [10]. Recent evidence suggests that the Earth System may have already crossed a planetary threshold in the glacier-interglacial cycle. At $2{ }^{\circ} \mathrm{C}$ the Earth may irreversibly enter a "hothouse Earth pathway" [1].

These transformational changes require transformational responses. Often development actions fail to address drivers of shocks and stresses, or root causes of vulnerability, and only result in superficial changes to systems [11]. This paper examines combination of actions which may lead to transformation in the land-climate context. It builds on the transformational adaptation literature to identify new types of at approaches at different scales, and approaches implemented in new locations to adjust to risks emerging from climate-land-society interactions [12-14]. The next section discusses risk, and how conceptions of risk are altered by examining climate-land-society interactions. Section 3 examines four case studies that deepen understanding about what it may take to adapt in ways that keep pace with, can address the intensity of, and prepare society to manage the scale of changes in climate-land-society systems. In Section 4 the article analyses characteristics of transformational adaptation which the case studies illuminated, and then concludes.

\section{Sizable Risks and Vulnerabilities Arising in Climate-Land-Society Interactions}

Working towards climate resilient, sustainable development requires an understanding of current and future risks arising from interactions between a changing climate, changing land-use, and changing societal patterns. The way risks arising from these dynamics are conceptualized plays a significant role in how, at what scale, and where these risks are managed. Contemporary thinking about climate-land-society risks and related measures to manage risk does not yet sufficiently inform adaptation efforts. Concepts that account for a broad range of climate-land risks to societal goals are needed. This would better enable climate science, policy, and practice to reduce harm to human welfare and ecosystems upon which they depend.

\subsection{Concept of Risk Affects Approaches to Adaptation}

In the current dominant narrative amongst climate policy and climate researchers, risk is characterized as resulting from a combination of hazardous events (often extreme events such as 
storms, floods, extreme heat), exposure of physical assets such as infrastructure, and vulnerability of human systems [15-18]. The way in which climate risk is described through the Intergovernmental Panel on Climate Change (IPCC) reports has, however, varied over time. Prior to the AR5 report cycle the term "risk" was not defined in the glossaries of assessments of IPCC Working Group II. The notion of risk as a function of hazard, exposure, and vulnerability became prominent in the IPCC Special Report on Extreme Events (SREX) [19]. The SREX adopted the disaster risk framing and focused primarily on climate-related extreme event hazards and related exposure and vulnerability, with passing reference to gradual, slow onset changes in baselines. The definition of risk provided in the IPCC AR5 WG2 glossary of terms is: "The potential for consequences where something of value is at stake and where the outcome is uncertain, recognizing the diversity of values. Risk is often represented as probability of occurrence of hazardous events or trends multiplied by the impacts if these events or trends occur. Risk results from the interaction of vulnerability, exposure, and hazard ... the term risk is used primarily to refer to the risks of climate-change impacts." This risk framing was again used in the most recent IPCC Special reports on 1.5 degrees and is likely to be used through the IPCC Sixth Assessment Cycle (AR6).

The physical characteristics of (primarily) climatic risks-manifest by hazards such as storms, floods, droughts, and temperature extremes have captured academic, public, and policy attention. Risk management has focused on reducing exposure by addressing physical elements of emergency, infrastructure, and input management. Examples include flood management and land management practices such as dams and drainage canals, irrigation, retention walls to prevent erosion, and farmers adjusting to changing climatic conditions by switching seed varieties. Discussions about "building back better" and "bouncing back" to normalized conditions prior to a hazard span discussions in both disaster risk management and climate adaptation [20,21]. Wise et al. [22] suggest that those adaptation actions that have been implemented have been "mostly incremental and focused on proximate causes" such as disruptive events, such as weather extremes. Less adaptation action has focused on long-term processes that interact with those disruptive events and create unique impact patterns. Wise et al. [22] point out that "by assuming adaptation decisions can be managed in a traditional risk framework, adaptation efforts have tended to be problem-oriented and reductionist in approach". The prevalent disaster risk framing does not yet sufficiently equip authorities to deal with many of the risks that affect human well-being in the 21st Century [23].

Emerging experience with climate-land-society interactions reveal complex and interacting systems subject to significant human influence (endogeneity). For example, decision makers govern areas experiencing shifting land use from rural to urban patterns, coinciding with demographic changes, shifts in where people live and work, and changes in the quality and quantity of rainfall and groundwater that affect the food supply. The sources of change that adversely affect people and ecosystems must, at a minimum, be viewed as a dynamic system which may also be experiencing a change in state [24]. Recent literature modeling different climate change and socio-economic pathways (SSPs) highlight the impacts of changing drivers and policy choices, for example of trade or land management, on risks of food price, coastal flooding and childhood health, for example [25-27].

\subsection{Need to Include Intensity, Rate of Change, and Scale of Change as Drivers of Climate-Land-Society Risk}

A review of climate-land-society interactions highlights three specific areas-intensity, rate of change, scale of change- the need to be better included in concepts of risks, and addressed through transformational adaptation measures:

Intensity of change in climate-land-society interactions are not yet well reflected in risk concepts. Current notions of risk and associated risk management only capture certain temporal and geographic elements of risk and do not yet empower society to address the intensity of risks, which may be variable over time. Figures introduced in the IPCC Third Assessment Report such as the "burning embers" graph illustrate how the intensity of different risks varies at different degrees of warming [24]. Reasons for concern, used in such figures, highlight the fact that numerous risks interact with each 
other to further affect intensity. For example, a large scale challenge for development will be to ensure food security for 9 to 10 billion people by mid-century with safer, nutritious food from the same area without increasing pressure on land and biodiversity [27-30]. Global food demand is expected to increase $60 \%$ by 2050 relative to the mid-2000s [31]. Growing populations in sub-Saharan Africa (SSA) is anticipated to triple the demand for cereals [32,33]. At the same time, yields of crops are expected to decline [9]. Further evidence is emerging that nutrition of food will be altered as a result of increasing greenhouse gas emissions, further increasing risks to food security [34].

The rate of change in climate-land-society interactions mostly eludes the risk discourse to date. A range of slow onset climate-related impacts do not match present-ways of conceptualizing and managing hazards, which are often treated as rapid onset events. This becomes important in anticipating disruption and helping society minimize and gird for such impacts [35,36]. Gradual processes such as annual increases in urban heat, gradual build-up of coastal megacities and informal settlements in areas at risk from floods, storm surges, salt water intrusion, or other disruptive forces might evade attention until the cumulative exposure to impacts is already substantial. When society's attention is drawn to the disruption, many opportunities may have been missed to preempt and plan for these patterns of change. Many of the systems in place to release support to address climate-related risks draw on the idea of an event trigger, such as a hazard like an extreme storm, heat episode, flood, or drought [37-40]. However, combinations of society-land-climate interactions such as prolonged or intense heat stress at intensities not commonly experienced in the past negatively impact crop yields and food systems, livelihoods of people, on mammals, and ecosystems but may not meet the trigger classification [41-43].

The scale of change is not fully incorporated in risk concepts. A common response of society to change is take steps to maintain the current system or to accept gradual changes in particular spatial scales [44]. Current notions of risk do not yet capture the scale of change experienced today in climate-land-society interactions. Some examples of large scale land and climate change interactions resemble changes in state such as loss of biodiversity in the Amazon and continued deforestation. Such changes may lead to potentially irreversible "savannization" of the forest area [45]. Modeling of phenomena such as heatwaves, forest fires, and aquifer replenishment suggest intense impacts at large geographic scales [46-48]. The effects on human development of large spatial scale challenges are already becoming evident. These include deepening poverty and livelihood and food insecurity, and some cases of displacement or planned retreat [49-52]. The scale of change poses challenges for managing risk. There is an increasing need for landscape scale measures are needed to reduce exposure and vulnerability.

Current concepts of risk need to consider the dynamic changes in climate, social, and earth systems to foster approaches to manage these interacting risks while striving towards sustainable development. The next section will examine case studies from climate-land-society interactions that illustrate adaptation that captures some of these elements of dynamic risk.

\section{Case Studies: Adapting to Changes in Pace, Intensity, and Scale of Risks and Vulnerabilities}

Building on discussion of risk in Section 2, in this section we draw on examples from practice of managing climate-land-society interactions. The four cases in this section illustrate transformational approaches to deal with dynamics emerging from changes in climate, land, and society. Transformational adaptation, while interpreted widely [14], is broadly concerned with deliberate action and intention with the goal of bringing about major change-the willingness to allow systems to change their fundamental attributes $[13,53]$. Transformative adaptation has been described as new approaches, at different scales, and in new locations [12]. The case studies in this section uncover additional characteristics of transformational adaptation that take into account the rapidly emerging changes and dynamics between climate, land, and societal systems.

Fresh insights about risk and transformational adaptation can be gleaned by looking at risk and vulnerability through a lens of climate-land-society interactions. Evidence about managing 
land-climate interactions illustrates processes and characteristics of risk that have been less illuminated in risk management discussions to date. Such risks include slow onset processes like loss of biodiversity and ecosystem services, sea level rise, changing availability of freshwater, and desertification. Table 1 below summarizes the four case studies discussed in this section.

Table 1. Case studies insights about climate-land-society risks and transformation adaptation.

\begin{tabular}{clll}
\hline Case & \multicolumn{1}{c}{ Challenges } & $\begin{array}{l}\text { Insights about Risks Arising from } \\
\text { Climate-Land-Society Interactions }\end{array}$ & $\begin{array}{c}\text { Transformational Element } \\
\text { (after Kate et al. [12]), } \\
\text { Essential Issues to Note }\end{array}$ \\
\hline $\begin{array}{l}\text { Semarang, } \\
\text { Indonesia }\end{array}$ & $\begin{array}{l}\text { Rapid conversion of land from rural } \\
\text { to urban uses, urban flooding }\end{array}$ & $\begin{array}{l}\text { Highlights the pace and scale of } \\
\text { actions needed to address flooding } \\
\text { concerns with rapid land use change } \\
\text { and urbanization. }\end{array}$ & $\begin{array}{l}\text { Illustrates need for novel } \\
\text { approach at new scales }\end{array}$ \\
\hline Nepal & $\begin{array}{l}\text { Negative impacts of flooding on } \\
\text { development }\end{array}$ & $\begin{array}{l}\text { Highlights the intensity of risk, and } \\
\text { illustrates how social support can } \\
\text { help affected populations reduce risk } \\
\text { exposure and vulnerability. }\end{array}$ & New approach, new areas \\
\hline Argentina & $\begin{array}{l}\text { Glacial melt and attempt to manage } \\
\text { water supply in a strong agricultural } \\
\text { community }\end{array}$ & $\begin{array}{l}\text { Highlights the pace and intensity of } \\
\text { risk; and illustrates use of national } \\
\text { law combined with strong local water } \\
\text { institutions and community. }\end{array}$ & $\begin{array}{l}\text { New approach and new scale } \\
\text { (glacier protection law, } \\
\text { institutions) }\end{array}$ \\
\hline Alaska & $\begin{array}{l}\text { Permafrost thawing and accelerating } \\
\text { coastal erosion affecting indigenous } \\
\text { lifestyles and settlements, } \\
\text { community-based relocation }\end{array}$ & $\begin{array}{l}\text { Highlights the pace, scale, and } \\
\text { intensity of risk; and illustrates } \\
\text { use of community-based relocation to } \\
\text { a new place, and adjustment of } \\
\text { cultural values. }\end{array}$ & New location/relocation \\
\hline
\end{tabular}

\subsection{Ecosystem Services and Regulating Land-Use Conversion to Preempt Flood Damage in Indonesia}

As climate change results in globally changing weather patterns, the intensity of rainfall events from year to year becomes increasingly uncertain. Agricultural practices and the natural landscape provide services that slow or retain rainfall runoff, such as water storage in rice paddies. Such landscapes effectively create reservoirs that manage storm water runoff and help buffer flood events in downstream regions of their watersheds. When land conversion results in hardening of natural or agricultural landscapes, these reservoirs are lost and the beneficial water management services that they provide for downstream communities are replaced by increasingly efficient drainage, which leads to more frequent and severe downstream flood events. Management that increases developed areas, at the expense of natural land cover or agricultural land, has the potential to accentuate, rather than buffer, the negative effects that climate change has on local populations. This case study focuses on land management strategies that can be used to help increasingly developed landscapes maintain their ability to buffer storm water flow and increase their resilience to changing weather patterns. The Garang River basin, located in central Java province Indonesia, has experienced increases in flood occurrence coinciding with conversion of the natural landscape to agricultural and urban uses. Initially, the effects of flooding were most prominent in the lower basin, which flows through Semarang city. More recently, areas of the upper watershed have also experienced increasing localized flooding, impacting property and displacing residents [54].

Natural landscapes moderate storm water run-off through a mix of ecological processes including interception, evaporation, infiltration, and storage. These processes combine to slow and divert water run-off throughout a catchment area, ensuring that the run-off is metered out slowly over a period of time. As the existing soil and vegetation in a landscape is replaced by impervious surfaces run-off is no longer slowed and metered out over time. Instead it runs off quickly, concentrating the peak flow and leading to increased flood risk.

Although the population in the upper basin, Semarang Regency, has not been expanding as rapidly as in Semarang City (1.55\% annual growth for the City versus $1.23 \%$ for the Regency from 2000 to 2015), it has still experienced steady growth. As the population in Semarang Regency has increased there has been a transition from natural landscapes to agricultural uses, and then into urban development. Within the lower basin in and around Semarang City, $73 \%$ of the available landscape 
is currently committed to urban development. In the Regency, only $32 \%$ of the landscape has been converted to urban development [55]. However, if the population growth continues apace, then the percent of the upper basin that is developed will certainly increase $[55,56]$.

In the late 1990s and early 2000s, there was a concerted push to implement engineering-based flood risk reduction measures. These measures-dams and expanding the West Flood Canal, which is the expanded channel in which the Garang River passes through Semarang City-were intended to alleviate flooding in the lower basin [57]. The engineering interventions in the lower basin were sufficient to ensure the Garang River through Semarang City could accommodate a 100-year event (under 2002 landscape conditions) without flooding due to over-topping from the river channel. When construction was finished on the Kreo River dam and west flood canal expansion, Semarang City could handle a 100-year storm under 2002 land cover conditions. However, in 2018, due to land cover changes, the system was reduced to only being able to safely accommodate a 58.5-year flooding event [58]. Depending on the rate of future land conversion, the flood management capacity of the system will be further reduced to a 1-in-50 year event [58].

Interventions within the Garang River Basin have raised questions about how to alleviate flood risk in the future. It is not yet clear the degree to which infrastructure investments and engineering approaches alone will be able to continue to protect Semarang City from severe flood events. Several major changes are worth noting: The city is experiencing subsidence due to ground water extraction and soil compression averaging $4 \mathrm{~cm}$ per year, which increases exposure to inundation if over-topping occurs [15]. The subsidence combined with tidal inundation lead to inundation even without over-topping, but the tidal inundation also backs up river flow, which reduces conveyance capacity and makes channel over-topping more likely (Mechler 2004). The recently expanded canal is also losing capacity due to sediment deposition, which reduces the size of the storm event the canal can safely handle without over-topping. Finally, changes in land cover in the upper basin are increasing peak flows for storm events [58].

An international non-governmental organization has been working with local communities in the Regency to understand the extent to which land use changes are increasing flood risk and the options for combatting this increased risk. Communities are now planting trees, and installing storm water swales, and dry wells-considered cost-effective and locally appropriate. However, to keep pace with annual increase in run-off due to new development of between $5 \%$ and $20 \%$, it is calculated that up to 249 hectares of trees would need to be planted, and 1814 infiltration wells and 1314 swales would need to be installed [58]. The scale of interventions including the land and funding needs is significant.

Lessons learned. The ecosystems-based approach (among other aspects of the intervention) is a new approach for the area and a transformational element. Previous solutions such as the dam built upstream of Semarang and the widening of the floodway through the city address the symptoms of landscape change that is occurring within the basin, but do not provide a sustainable solution for the basin. Yet, purely ecosystem-based solutions are quickly overwhelmed by the pace and intensity of change (climate as well as social-i.e., urbanization) overwhelms current efforts. As the percent of land cover conversion from agriculture to urban development increases, the number of interventions needed to keep pace increases well beyond the capacity of community organizations and non-governmental organizations (NGOs).

For the case of Semerang, the characteristics of successful transformational adaptation must incorporate a balance of the three possible solutions-limits on land use conversion, regulation of storm water for new developments, and a basin wide effort to implement ecosystem and other interventions at a greater scale.

Semerang faces limits to safe, longer-term land use conversion. Rapid urbanization and conversion from rural to paved urban areas combined with changing frequency and magnitude of rainfall is rapidly increasing flood risk. Long-term support to ensure sufficient interventions can be put into place will be needed in the future. Even at the lower levels of land cover conversion, it is difficult to find space within the Semarang Regency to implement the necessary interventions to keep pace with 
storm water increases. Without effectively addressing the underlying cause of flooding-the dynamic interactions of climate, land use, and societal change-flood risk interventions will not keep pace with the damage [58]. The current and historic approach to flood risk has been to build dams and expand the channel in the lower basin. Even now, there are more dams planned for the upper basin. This engineering approach addresses the symptoms without addressing the cause of the flooding. As the analysis shows, this makes the solutions temporary-they help in the short term, but eventually the flood risk returns as more development occurs in the upper basin. In addition to not addressing root causes of flooding, the engineered infrastructure solutions are enabling the flood risk to be alleviated short-term without addressing the other problems development is causing.

Regulation has the potential to balance development and storm water management. Land use planning needs to be done in a more concerted manner, with predetermined limits set for the amount of agricultural land conversion that can occur within a given year. Semarang, Regency would need some combination of effective regulation to encourage infill and use other high-density development strategies to help achieve these targets. Regulation may also be needed to limit and enforce the amount of urban development that is allowed need to be set in conjunction with requirements for storm water management from new development-the lower the amount of storm water management that can be delivered, the lower the conversion from rural to urban land uses should be.

Combining new approaches with new scales of tree planting and other measures are needed to keep apace of the flooding risks associated with rapid urbanization. Absorbing storm water is only one ecosystem service being lost from the landscape-food production, climate regulation (at all scales), air quality regulation, water quality regulation, aesthetics, and many other services are also being impacted. The flooding is in some ways an early indicator of the disruption to community resilience that is occurring. Community resilience is being reduced through the widespread loss of ecosystem services even as the proposed engineered solutions provide temporary relief from the flood risk. Ecosystem interventions can restore ecosystem services back to the landscape while addressing the flood concerns. For instance, tree species (e.g., food trees) that provide multiple community benefits can be planted to alleviate flood risk.

Transformational adaptation requires the landscape factors that are causing flooding in the basin be included in a sustainable solution. This means balancing limitations on urban growth with storm water management requirements for new development, while also pursuing a suite of interventions that can return lost ecosystem services to the landscape. Without all these factors, Semerang will face challenges with flood management and may lose ground. To ensure further discussions and the development of a sustainable approach, a basin-wide forum has been created that includes representatives from agencies within Semarang Regency and Semarang City, as well as community stakeholders, representatives from the Universities, and large developers.

\subsection{Diversifying Income Sources and Land Use Practices to Reduce Negative Coping to Floods in Nepal}

Nepal is a country highly vulnerable to climate change. Expected impacts include increases in extreme events and flooding. Central and Western Nepal experienced several devastating flooding in the summer of 2017 which resulted in 180 deaths, 445,000 displaced households, 63,000 fully destroyed homes and 118,000 partially destroyed homes [59]. In addition to this, the Ministry of Agriculture reported that 10 million U.S. dollars' worth of crops were destroyed and nearly 70,000 livestock died due to the flooding (ibid). Flood impacts set back development and well-being of affected households, negatively affecting nutrition, savings, livelihoods, and education. This case study documents efforts by civil society to support climate change adaptation and build resilience to flooding in the Far Western region of Nepal. An integrated intervention model ("nexus model") was developed by the Managing Risk through Economic Development (MRED) Program that combined traditional community-based flood risk reduction approaches with interventions designed to increase market access for crops that have risk reduction potential. Further details are available in [59]. 
Each community participating in the MRED program went through a participatory disaster risk assessment (PDRA), which combined a vulnerability risk assessment (identifying and prioritizing hazards/risks) with a context analysis of the ecosystems, livelihoods and markets that exist in each community. The results of the PDRA provide a list of prioritized interventions that respond to the relevant risks, the ecosystem and climate conditions, and which are relevant to the community livelihood and local market opportunities. These interventions included planting sugarcane on erosion-prone riverbanks to prevent river cutting while increasing productivity of marginal lands, and planting fodder species in marginal lands of hilly areas to mitigate landslides while also acting as an input for growth of the dairy sub-sector. Complementary interventions addressed livelihood vulnerability by building access to financial services, improving land management and protection mechanisms on communal risk-prone land, and addressing gender-based norms and attitudes that limit women's ability to support risk reduction.

A quasi-experimental study was conducted to compare the impact of the 2017 floods on households receiving interventions vs non-beneficiaries. Twenty-eight nexus communities were selected for this study. They were matched with an equal number of communities in the same municipalities who shared as many characteristics as possible but were not beneficiaries of programming. In these communities, 472 households that had participated in nexus interventions were examined, while 292 households served as the control group (764 households in total).

The study employed propensity score matching which requires a 2:1 ratio of intervention and non-intervention households. Unbalanced caste composition and elevation levels of treatment and control groups may have biased some study results.

As documented by Scantlan et al. [59], households participating in interventions reported having savings before the 2017 monsoon more often than non-nexus households $(70 \%$ versus $50 \%, p<0.01)$. They were $16 \%(p<0.01)$ more likely to have household level disaster risk reduction plans. Nexus households were also more likely to take appropriate actions after receiving early warning messages. These actions included being $21.5 \%$ more likely to evacuate to a safe place $(p<0.01), 16.9 \%$ more likely to collect documents and assets $(p<0.01)$, and $24.9 \%$ more likely to evacuate livestock and warn neighbors. Households were $23 \%(p<0.01)$ more familiar with risk-mitigating agricultural techniques. As a result, MRED households suffered $8 \%$ lower agricultural losses, and were $11 \%$ less likely to take out informal loans (with high interest rates) to recover losses. They reported higher-levels of dietary diversity $(0.5$ more food groups, $p<0.01)$, lower reliance on negative food coping strategies $(-3.35$ points on the coping strategies index score, $p<0.01)$, experienced less income disruption $(-12 \%, p<0.01)$ and suffered $7-9 \%(p<0.05)$ less agricultural input losses than non-nexus households following the flooding events. Ultimately, they were $12 \%$ more likely to strongly agree that they had recovered $(p<0.01)$, and were $21.5 \%$ more likely to be fully confident in their ability to cope with shocks in the future that non-nexus households $(p<0.01)$.

Marginalized groups were not able to achieve the same positive outcomes as more privileged groups in target areas, suggesting social inequalities may have a large influence on outcomes. More privileged caste groups (Brahmin/Chetri) relied less on negative coping mechanisms to access food, had better diet diversity and took out fewer high-interest informal loans than the Dalit caste group (the most marginalized caste group in Nepal) after the 2017 flooding events. Male heads of household lost fewer crops due to flooding and relied less on high-interest informal loans than female heads of household after the 2017 flooding events.

Lessons learned. Researchers have argued that transformation involves changing states entirely, for example shifting from dependence on subsistence agriculture to having income sources with differently-distributed weather exposures, such as cash-generating tourism-based livelihoods (Jones et al., 2018). This case study highlights the process through which communities and households can begin to transform. Before nexus interventions, some flood vulnerable households diversified income sources by sending household members for seasonal work in India. But seasonal migration 
served mainly as coping strategy, allowing households to recover from individual events, but not fundamentally transforming core socioeconomic structures to deal with changing threats from floods.

The Nepal case takes a systems approach to increase the resilience of socio-economic structures. The MRED program identified needed transformations in core socioeconomic structures by using a systems approach-examining the integration of markets, potential for different income sources, financial services, gender and community inclusion. Market-based incentives were used to nudge behavior and promote long-term and sustainable investment in adaptation. When crops planted for flood risk reduction also earned a profit, farmers not only reduced risk but were better able to respond to shocks, and were incentivized to continue adaptation and risk reduction efforts. Households had greater security, feeling that they can move forward and live healthy and productive lives. However, the study also shows that it is important to actively address discriminatory social norms and aggressively promote inclusion. Marginalized individuals may not be able to participate in market systems. Social protection or tools such as universal basic income can be used to help buffer shocks to households.

The MRED program approached land use in new ways to reduce vulnerability. In the MRED program, communities identified new interventions (growing sugarcane) in a new place (silted land), thus transforming adaptation possibilities. Using silted land for sugarcane production increased the productivity of this land and protected the marginal land. Households were no longer as vulnerable to exposure from hazards.

\subsection{Glacier Protection Law and Water Governance in a Strong Agricultural Community in Argentina}

Mendosa, Argentina provides a case study of transformational adaptation that illustrates how water governance has attempted to address the pace and intensity of risk to local water sources [60,61]. Mendoza lies in the southern central Andes Region on the eastern side of South America and has a warm, arid climate conducive to cultivating wine. The Central Andes are full of "small" glaciers (oftentimes referred to as 'glacierets'), such as those of less than one hectare in area. The volume of these numerous small glaciers in the Andes may contribute more to ecosystem hydrology than all the larger glaciers combined. One small glacier contains enough fresh water for a household for three or four decades. In Mendosa, snow accumulates during cold winters and in spring melts and results in Mendoza river runoff, peaking in December and January providing water for hydroelectricity and irrigated agriculture (Montana and Boninsegna 2016).

Irrigated agriculture commenced in the area in the 16th C and a unique "mendocina" culture emerged of Spanish immigrants 'beating the desert' and creating a sustainable land model (Montana et al., 2005). The resulting desert oasis contained $98.5 \%$ of the population and consisted of irrigated vineyards, viticulture, and horticulturalists; the remaining population consists of goat breeders who exist on the non-irrigated surrounding lands.

Melting glaciers and decreasing snow in the mountains, together with rising temperatures during the present century have increased the water deficit and compromise Mendoza's oasis survival (Montana and Boninsegna 2016), as well as problems with increasing soil salinity. Infrastructure-based adaptation to increasing aridity occurred in 2002 with the building of the Potrerillos dam, but the geographical benefit was at the scale of the oasis. The dam modified the natural flow of the Mendoza River benefiting irrigators and the oasis residents but increasing the vulnerability of the pastoralist guarpes who no longer receive the surplus run off during peak snow melt that resulted in fodder for goats in the drylands $[62,63]$.

To advance transformational change, national and provincial scale efforts require unity. Although a national Argentinian climate change strategy exists, it has little relevance to the province of Mendoza; Mendoza's provincial plan promotes energy and water efficiency [64]. The integrated land use plans and water plans such as the Master Plan for Mendoza River Basin, make little mention of climate change and adaptation. However, programs targeted specifically at small and medium agricultural producers provide financial assistance for adaptation measures and alleviate change in farm income 
when droughts occur. In Mendoza, efforts targeted to the individual agricultural producer level require policy cohesiveness at the larger provincial and national scale, such that climate change and drought are included in land and water plans [61].

Mendoza's 500-year history of water management has resulted in a strong institutional water structure including a provincial Departamento General de Irrigacion (DGI), an intricate system of Basin Councils governed by water rights holders and a General Users Assembly populated by water rights holders. These strong water institutions govern water in a supply side manner, reducing water to rights holders proportionally during states extraordinary water shortage (M.A.). 2010-2014 were years of water emergency due to severe drought [65]. Demand side management, and optimization of water allocation by producers and their crop demands is impossible given the rigid supply side institutional culture [61]. Due to this, adaptations are made by wealthy irrigators accessing groundwater depleting aquifers, new development of vineyards situated higher in elevation closer to the water source, and conversion of established vineyards to residential developments whereby flowers and gardens of wealthy homeowners hoard sought-after water (ibid).

Transformative change occurred when the strong oasis viticulture of Mendoza supported the passing of a Glaciers Preservation Law N 32.016 (2010) that provides for minimum budgets to protect the national glacial water sources that the Mendoza oasis relies on. Argentina's glacier law establishes that all of Argentina's glaciers and its periglacial environment (permafrost areas which include water/ice saturated grounds) are to be protected, irrespective of size. In 2008, Argentina's federal Environment Secretariat discovered a forgotten Glacier Protection Bill in the national Congress which had not had enough political support to pass. The head of the secretariat addressed the legislative members, generating enough political support for its passage. Legislators may have assumed the Glacier Protection Bill aimed to protect Argentina's colossal Patagonian glaciers, possibly overlooking the fact that thousands of smaller glaciers in the Argentine Central Andes are critical to the provision of water to downstream ecosystems. The Glacier Protection Bill went unopposed and was voted unanimously in late 2008 by Congress. This unique federal law was the result of a successful lobby by Mendoza producer groups and environmental groups to protect the glaciers and headwaters from mining development that would negatively impact the sustainable land management of the Mendoza oasis (ibid).

An inventory of glaciers prepared in 2018 identifies up to four mines that are not yet complying with the glacier law. The inventory and law is effectively stalling further mining projects and bringing the conflict between mining and sustainable land management (via access to pristine glacial and mountain runoff) into the political arena [61].

Lessons learned. In Mendosa, communities in an otherwise arid environment saw a risk of glacier retreat and headwaters as a material threat to their survival and livelihoods. The community was not unanimous in views about how to manage the glacial and groundwater supply. Yet, together they took a significant step with glacier preservation law that had not previously been in place at a national level. The national glacier protection claims that all of Argentina's glaciers are "public property" and "strategic reserves of water."

The law bans resource extraction (mining, oil) in glacial watersheds, and restricts industrial activity, which expands the notion of what a periglacial area constitutes. The glacier protection law established a glacier inventory to monitor environmental impacts of commercial projects, ensure glacier protection, and impose penalties on polluters. Legal scholars back the constitutionality of the Glaciers Act but mining association members promised to fight any implementation and argue that provinces have absolute legislative authority over natural resources. Provinces maintain control over their natural resources and can grant permission to access them (such as to mining companies), while environmental protection is a power retained by the national congress. Mining and other groups have contested the law and the Supreme Court ruled the glacier law constitutional. Nevertheless, the opposition by powerful mining interests have resulted in uneven application of the Glaciers Act. 
Adjusting irrigation regulations and practices could address unused water rights. Water resource use in Mendoza is characterized by a high percentage of recently-established major international wine producers using modern high-efficiency irrigation methods and drawing on ground water. In contrast, long-standing smallholders using traditional low-efficiency irrigation techniques dominate the use of surface water. Rigid institutions reinforce historical management of water supply and water rights. These institutions make it difficult to reallocate water resources from long-standing smallholders to international corporations. In Mendoza, the existing system of legal rights for groundwater extraction and use requires an annual charge ("canon") for water determined by the diameter of the well. The system does not have provisions to encourage efficiency of irrigation use or discourage waste in water-stressed areas. The department of irrigation could generate considerable legitimate additional revenue by changing its fee collection to charge more for water in certain areas like groundwater use restriction zones. Historical water rights distribution favors surface water users and surface water irrigation infrastructure has usually enjoyed subsidization. In comparison, in recent years groundwater users such as large international wine producers have to pay for well drilling and pump installation and pay around seven times more for irrigation.

Water distribution could be allocated by season and crop. Water allocations have been historically tied to social relations and through trading [61]. For transformational adaptation of water governance, in addition to the national glacier protection law, Mendosa would need effectively to switch water distribution at different times of year and for different crops. This is not yet part of the institutional water culture. For example, a clause in provincial water law does require "beneficial use" and prohibits stockpiling of groundwater rights. However, in practice, groundwater rights tend to be granted 'in perpetuity' in the area, making "clawback" difficult at the time of mobilizing finance for irrigation modernization to pressurized systems like with drip and micro-spray application [66]. This rigidity contributes to a tendency to use the water that was "saved" to extend the irrigated area. Further, although it is not allowed to sell rights, the department of irrigation serves as an intermediary in the sale of excess surface water allocations. The local cost of irrigation modernization is at a level such that surface water irrigators have little incentives so far to invest in water saving measures. Additionally, the department of irrigation does not yet have sufficient legal or financial power to redistribute excess surface water to areas without rights, or reduce rights along river banks where water use can sometimes be inefficient [67].

\subsection{Indigenous Communities in Alaska Employ Managed Retreat from Permafrost Thaw and Coastal Erosion}

This case study examines the experience of community based, "managed population retreat" as a transformational adaptation strategy of indigenous people in coastal Alaska. Kivalina, Alaska is located at the tip of an eight-mile barrier reef about 80 miles above the Arctic Circle. The 400 Inupiat Eskimo villager hunt and fish (seal, walrus, whale, salmon and caribou) for their food supply. The isolated whaling community faces storm surges, sea ice encroachment on land, coastal erosion, landslides, and earlier and shorter hunting seasons that threaten the integrity and safety of their homes and village infrastructure. Rapid permafrost thaw and coastal erosion threaten the traditional lifestyles of affected communities, which they are striving to maintain [68-72].

Relocation has been a long-term issue in Kivalina. In 1953, overcrowding and erosion motivated a public vote for relocation, but it was turned down with a 50/50 vote; a similar vote and result occurred in 1963. Since 1953, when the village covered approximately 54 acres, erosion activity shrank the area to less than 27 acres, making relocation more necessary. In 1992, residents voted to begin the process of relocating. The Kivalina village council asked the State of Alaska and the Federal Government for help in community-based relocation to a safer location that would allow the community to live in less dense proximity [73].

In 2006, the U.S. Army Corps of Engineers released the Kivalina Relocation Master Plan which examines alternatives for the village. The three options were: Relocation (e.g., Imnakuk Bluffs, Simiq, Tatchim Isua, Kiniktuuraq, Igrugaivik, or Kuugruaq), improve the existing site, or do nothing. 
The Kivalina village council assessed safe alternatives for staying or moving. As coastal erosion is constantly eroding the ground where Kivalina is situated, doing nothing is not an option. Similarly, existing conditions of erosion, overcrowding, and poverty make improving the site structurally an inadequate option. Relocation was determined to be the preferred alternative and was supported by the 2006 Alaska Village Erosion Technical Assistance Program study. The study estimated the cost of moving Kivalina is $\$ 95-125$ million (ibid).

Despite relocation being determined as the best option and of the upmost urgency, many of the sites examined in the Kivalina Relocation Master Plan as potential relocation options were declared not suitable because of cost, susceptibility to erosion and flooding, and/or social and cultural objections. The village identified a site about eight miles away in Kiniktuuraq; yet U.S. Army Corps of Engineers deemed this site unsuitable because flooding and erosion risks would cause additional problems. As an alternative, the corps suggested Tatchim Isau and Imnaaquq Bluffs, but these sites were too expensive and would not allow villagers to pursue their indigenous culture and traditional lifestyle. The relocation process progresses slowly as the village seeks technical assistance and funding to support their efforts. In the meantime, severe coastal storms, thawing permafrost, and shoreline erosion continue to threaten both life and property in the area. So far, relocation has been delayed by diverging views about where Kivalina could move, at what point in time, and at what cost. The US Army Corps of Engineers determined that the site proposed by Kivalina was unsatisfactory because of exposure to flooding and coastal erosion, exacerbated by permafrost thaw. The engineers estimated a time window of 5-10 years before existing locations are overcome by erosion and flooding problems [52].

Kivalina continues to apply for state and federal funding and support to build capacity and technical assistance to facilitate the relocation process. The village faces several challenges including choosing appropriate sites, locating funding, and dealing with internal social issues such as overcrowding and poverty.

Lessons learned. The ongoing process of community-led relation suggests that a combination of participatory assessment of problems and solutions, adjusting current laws to overcome to local adaptive action, and fostering innovative institutional framework for relocation will contribute to success [73]. Summarizing the findings of Bronen and others, there is a need for institutions to preempt risks to communities, incorporate the climate-land change-societal aspects of risk into planning, and provide for effective contingency measures if and when managed retreat becomes necessary for Alaska coastal communities.

Participation and integration of social and ecological well-being into adaptation planning. Perhaps especially because of the indigenous knowledge and unique cultural heritage of affected coastal communities in Alaska, part of managed retreat in this case includes a federal grant to empower community members to monitor local social-ecological processes. This ongoing process helps inform communities' self-directed adaptation efforts. Currently, "citizen science" is used in Kivalina, Shishmaref, and Newtok to document accelerating rates of erosion, damage from severe winter storms, and threats to human safety and property. Local assessments should be integrated into regional and national assessments to support collaboration between community leaders, researchers, and government which reduce the social impacts of these coastal risks.

Amendments of existing laws may be needed for transformational adaptation. In an examination of institutional constraints of relocating communities in the United States, Bronen [73] suggests amendment of the Stafford Act to include gradual geophysical processes, such as erosion, in the statutory definition of disaster. By amending relevant federal policies like the Stafford Act, the President of the United States would be able to make a declaration that would release federal resources that could in turn be applied to preempt risk and help communities and the state plan. Additionally, it would be helpful to adjust laws in ways that allow federal disaster relief funding to be used towards managed retreat vis-a-vis climate stressors. Further, when "durable solutions" for human settlements in a 
particular area becomes unfeasible, funds could facilitate federal agencies building new infrastructure and relocating entire communities.

An adaptive governance framework allows a continuum of responses from preempting in situ risk to contingency measures that facilitate relocation. Traditional disaster risk management interventions focus upon restoring infrastructure. Such approaches may face increasing challenges where the changes are so rapid, intense, and widespread that the locations are no longer safe for human habitation. Kivalina and communities like it are designing a forward-looking community-based relocation program that incorporates resilience to continued climate change. In cases where climate-land-societal change is so profound, Bronen [73] notes, "community relocation involving permanent population displacement may be the only viable adaptation ... to protect residents from climate-induced biophysical changes that alter ecosystems, damage or destroy public infrastructure, and repeatedly endanger human lives." Governance frameworks are required which allow community members to reconstruct their lives-including a sense of place and belonging, schools for their children, places to worship-and their livelihoods in a location that offers protection from extreme events as well as gradual changes accompanying climate-land-society interactions. Indigenous coastal communities such as those in Alaska would benefit from an institutional framework that authorizes state and federal government agencies to provide them technical assistance and funding. A participatory process is needed that allows communities and government authorities to determine what specific steps need to be taken at what points in time to begin a relocation planning and implementation process.

Across the world, current legislation is geared towards providing resources for emergency situations rather than resilience and development contexts. Disaster-related situations and human mobility are often managed with the assumption that people will go back to their areas of origin once things get back to normal. For example, temporary visa waivers are common when an extreme event happens, as illustrated in the extreme hurricane season in the Caribbean in 2017 and earlier events in the region $[74,75]$. Recently, contingency arrangements are facilitating adaptation in new locations such as identification cards, labor retraining programs, regional mobility arrangements, and mobility of social benefits across borders [76,77].

Emerging climate and development policy related to human migration can provide a stepping stone for transitions between immediate-term use of existing approaches to longer-term changes. These could include population shifts from hazardous to safer locations, new arrangements for governing of borders and mobility, and planning for livelihood viability in different locations. The degree to which these contingency arrangements address the intensity, rate and scale of change (the elements of risk discussed above) will influence the extent to which adaptation in new locations improves human welfare in the long-term.

\section{Analysis: Characteristics of Transformational Adaptation to Climate-Land-Societal Change}

Each of the case studies presented above illustrate risks arising from the interactions of changes in land and climate systems, and attempts to adjust so that human well-being is not harmed. The cases present risks and vulnerabilities at a subnational scale, and one of the questions about adaptation is how to deal with sizeable risks, which may vary considerably depending on the extent of the system affected and how society perceives climate and land impacts. Acknowledging this limitation, this section analyzes some of the common characteristics that feature in how different populations are grappling with the changing pace, intensity, and scale of risks that threaten the development goals of the people in those locations. The cases illustrate new combinations of approaches in given locations, which foreshadow changes in approaches that may be taken at greater scales, and adjustments that involve new locations [12].

\subsection{Buffering Human Well-Being through Packages of Interventions}

The case studies show combinations of interventions that are intended to buffer people and help avert losses that can occur when they use negative, or maladaptive, coping measures. Examples 
of such negative coping measures include short-term actions that help people bridge moments of stress and which undermine longer-term ability to achieve their goals and recover from setbacks. Without buffer, people who face stress often consume savings, sell productive assets, take children out of school, endure deteriorating health instead of getting medical help [78]. The Nepal case study highlights a set of measures intended to improve household resilience to floods and other climatic-land stressors-complementary livelihood protection, community involvement, as well as institutional and physical measures [4]. Such approaches are relevant to land and climate interactions.

People suffer less from a local disruption if they are able to buffer the impact of disruption and diversify their income sources which are independent of the disruption [79]. Studies from Kenya, Somalia and Ethiopia show that consumption support can be useful during slow onset droughts. Different forms of livelihood diversification and support may also play important roles in adaptation packages in areas where land holdings are so small that maximizing productive potential will not ensure food security [80]. Adaptation packages, as seen to a degree in the Nepal case study, utilize consumption support in the form of cash or food assistance, transfer of an income generating asset (such as a livestock) and training on how to maintain the asset, assistance with savings and mentoring to reinforce learning and provide support. Studies show that such approaches can help people avoid or even graduate out of poverty traps with lasting positive impacts of consumption support on income, as well as food and nutrition security [81,82].

Research to date suggests that investing in resilience building activities, which increase household income by US $\$ 365$ to 450 per year in these countries, may be more advantageous and timely for household life cycles than providing ongoing humanitarian assistance. In Ethiopia, Kenya and Somalia, every US $\$ 1$ spent on safety net/resilience programming results in net benefits of between US\$2.3 and US\$3.3 [80]. Further, some research suggests that expanding financial inclusion, disaster risk and health insurance, social protection and adaptive safety nets, contingent finance and reserve funds, and universal access to early warning systems could save $\$ 100$ billion USD a year, if implemented globally [79]. Adaptive safety nets and universal basic income may be useful during times of intense and prolonged stress in climate-land systems [83]. Both can help buffer the impact of shocks, by smoothing consumption, and therefore lessen risks.

\subsection{Enabling Capacity with Institutional Processes}

The case studies presented here illustrate the need to focus not only on a possible outcome, but to allow for the process of adaptations which often occur in a series of steps enabled through institutional processes. The degree of change involved in adaptation may require different levels or types of capacity to be built to respond to or anticipate the dynamic changes in climate over time. Adaptation measures that involve cultural, social or economic shifts can present challenges for those involved, and support mechanisms in institutional processes will need to accommodate these shifts in ways that help foster adaptive approaches. [84]

Each case study featured participatory processes in which affected communities engaged in articulating their needs and shaping approaches that they help implement. Processes like participation affect the capacity for change because they help connect adaptation efforts with institutional rules and norms, and interconnected systems of knowledge and values that define the set of feasible and acceptable options that are considered [22,85]. The Alaska case study is an example where community members recognize a need and have a willingness to relocate and possibly transform their way of living, and also face institutional gaps and barriers [86]. Evidence shows that planning, involvement and agency of the affected groups will result in more durable solutions [87]. Indigenous groups pursuing community-based relocation in Alaska are combining traditional ways of knowing and "citizen science" to track how their land and the climate is changing. The state and federal institutions that could enable or hinder relocation proposals are geared towards releasing funds for emergency events (e.g., Stafford Act), rather than gradual processes of permanent change [73]. Relevant institutions may be locked into the current system and have many of their own reasons for resisting change. Hence institutions also 
play a significant role in enabling or hindering adaptation in line with the pace, scale, and intensity of change in climate and land systems [88].

Community-based relocation has yet to fully play out in Alaska, yet other examples of relocation that lacked community involvement have showed significant decline in human well-being and counterproductive results (ibid). The case studies presented here suggest that the capacity to adapt in step with the magnitude of changes in climate and land are influenced by a range of factors: Social, ecological, economic and political factors which will all have their own drivers and also change over time $[84,89]$. Adger et al. posit that the process of adaptation and potential limits are endogenous to the ethics, knowledge, attitudes to risk and culture related to the goals of adaptation-after the 2015 adoption of the Sustainable Development Goals and the Paris Agreement, ostensibly the broad goals focus on improving human well-being in the context of changing climatic-land-society risks. Whether or not societies that implement adaptation accept and view these goals and the ways to achieve them as legitimate affects how adaptation proceeds [90]. Participatory processes informed by expert and affected communities in the Global South correspond with more inclusive planning processes, which correspond to higher climate equity and justice outcomes. In comparison, adaptation processes that focus on building partnerships to institutionalize robust decision-making structures and capacity to secure funding and engage with communities enhance program stability and the possibility of ensuring an ongoing voice of societal groups in adaptation planning and implementation [91].

\subsection{Facilitating Ability to Change through Flexibility and Learning}

Approaches that include capacity for learning and change in the planning and implementation process foster adaptation $[64,92,93]$. The case studies presented here reinforce findings in the literature regarding the importance of flexibility and learning when grappling with adaptation decisions. Wise et al., (2014) [22] describe a series of iterative decision cycles, where a pathway to the future may be identified that appears suitable in the current time period, and which undergoes regular reevaluation so that further changes can be undertaken as required. The Mendosa case study illustrates this need for ongoing refinements: The national law protecting the glaciers was a first step to ensure the water supply, and then subsequent measures and changes were identified related to the institutions that distribute water [66]. This recognition of accommodating the process of change also arises in the economics of adaptation, where decision-making under uncertainty includes maintaining flexibility in adaptation decisions where possible and selecting adaptation options that can be revisited and adjusted as more information becomes available. [94]

Approaches that allow learning and adjustments during the process of planning are more likely to be in line with emerging risks and vulnerabilities associated with climate-land-society change [95]. Those adaptation strategies that offer the greatest options for changing in the future (flexibility) are those more likely to keep pace with rapid change and deep uncertainty. A strength of learning-oriented adaptation approaches is the ability to handle high uncertainty and inter-temporal complexity, through co-development with the affected communities, sectors or groups as examples of water planning illustrate [96,97]. Some work on cities and water planning find that flexibility-the ability to adjust the sequence and timing of actions-is a desirable characteristic that improves the functions and capabilities of water management systems even as climate-land-societal systems change [98] (Berry Gersonius et al.). Flexibility also allows the combination of different types of strategies to manage risks like floods or droughts, and allows a system to change over time [98].

The case studies contribute to the mounting evidence base about iterative, reflexive adaptation processes. Adaptive governance is emerging as a more collaborative, participatory and flexible way of working, aiming to achieve effective decision-making through co-innovation [99]. Adaptive governance features flexibility and iteration and will have a role to play as society grapples with the dynamic and evolving risks presented by climate change, land changes, and societal processes [100]. 


\section{Conclusions}

Examining interactions of land, people and climatic risks deepens understanding about how to preempt risks to sustainable development, plan for risks in ways that help minimize impacts, and put contingency measures into place. Adapting to the unfolding dynamics of climate-land-societal change requires a framing of risk that captures elements such as the intensity, rate, at scale of risks. Unfolding interactions between climate, land, and society illustrate that risks emerge from combinations of changing systems, rather than changes in climate isolated from land and societal systems. More fully encompassing these elements of risk will be needed in national and subnational adaptation policy and practice. For example, significant change in land and climate systems in places with populations mostly reliant on agriculture will require means of producing food and livelihoods sufficient for those dependent on those systems [101]. Loss of biodiversity and shifting of biomes will require deep changes in the practice of agriculture and forestry [51,102,103]. For areas facing sea level change and rapidly expanding coastal cities, adaptation strategies will need to include considerations of land values, zoning regulations, and possibly managed retreat options [104].

As the disruptive potential of climate and land change become clearer for society, there is increasing recognition that examples of transformational adaptation are necessary. This paper presented four examples of processes that are potentially transformational, or may lead to transformative outcomes. More empirical research is required to support further efforts. The case studies in this paper illustrate how notions of risk that capture elements like pace, intensity, and special scale of changes can help decision makers design new types of interventions, at new scales, and sometimes in new locations [12]. The characteristics gleaned from the four case studies in this paper contribute to understanding what it can look like to effectively adapt to the sizeable risks and vulnerabilities to human well-being. The case studies present additional characteristics that may be transformational in their intention and capacity to maintain human well-being in changing climate-land-society systems.

This paper points to several areas where future research can help inform transformational adaptation. For example, to match the level of action commensurate with the sizeable risks and vulnerabilities climate and land change bring to society, decision makers need to gauge the values people attach to positive and negative effects of climate-land-society interactions. Some literature attempts to estimate levels of needed adaptation investment, or costs of losing values like housing, assets, land, crop yields, or economic output. However, to justify investments, decision makers need to know much more about values at risk and how society views the variety of options to manage these risks [105-107].

More understanding is needed about the social discourse on what risks societies are willing to tolerate and what levels of acceptance societies have for different packages of interventions as current systems come under pressure from changes in climate and land. Decisions that affect whether actions help keep society on track to achieve its objectives will draw on evidence of societal risk tolerance and policy preferences. Examples are needed which reveal the contested and evolving process of transformational adaptation. Research about public acceptance for different actions at different points in time will be needed to bolster decision makers' confidence about investing in adaptation. Without understanding public acceptance of different policies, the cost of building prototypes or undertaking experiments as part of transformational adaptation may be an obstacle to action. A possible way to do this may be to jointly identify with the relevant decision-makers and stakeholders the points at which transformation may be necessary, to avoid costly and undesirable impacts. Data analytics already in use for consumer preferences may help ascertain design elements of aspects of transformational adaptation.

Further, the next generation of policy and research will reveal more about what risks mean to societal objectives (reflected in sustainable development goals). Social science and forms of participatory research can play a constructive role in filling knowledge gaps about societal risk tolerance and policy preferences. Research that deepens understanding about core functions of climate, land, and social systems will help reveal new combinations of ways to provide basic needs for people 
like safe communities and shelter, livelihoods, food and water. Additionally, research will foster deeper understanding of ways to help institutions become more flexible and less fragile, in ways that do not alienate decision-makers and the public. Further examples are needed from implementation, including lessons from unsuccessful attempts to adapt using different approaches, at different scales and in different locations. Further directions for future research in this area also include developing understanding of processes to move from the project level to scale up and out to a more system-wide transformation. Learning from other fields is likely to provide insights that could be applied to adaptation. This emerging experience is -needed now as countries around the world strive to realize their commitments to the Paris Agreement, and help countries realize sustainable development.

In conclusion, transformational adaptation is often perceived as a major large-scale intervention. The case studies in this article showed that, in practice, the process of transformation it is more likely to involve a bundle or package of adaptation interventions that are aimed at flexibly adjusting to the wider, dynamic change in climate-land-societal systems. As a global mosaic, transformational adaptation at a grand scale will occur through an inestimable number of smaller steps to adjust the central elements of human systems commensurate with the changes in climate and land systems. Understanding the characteristics of transformational adaptation offers insights about the degree to which interventions are designed to support the status quo and the degree to which adaptation measures might help keep society in step with reconfiguring climate and land systems as they depart from current states.

Author Contributions: For this multi-authored research articles, the authors' contributions to the respective sections are provided as follows: K.W., Z.Z., A.W., M.H. and D.V. conceptualized the paper; Z.Z., J.S., K.H. (Kenna Halsey), K.H. (Kevin Halsey), C.T., M.H., and K.W. researched and wrote the case study section; K.W. and A.W. provided the analysis; K.W. was responsible for the writing-original draft preparation, as well as the writing-review and editing.

Funding: This research received no external funding.

Conflicts of Interest: The authors declare no conflict of interest.

\section{References}

1. Steffen, W.; Rockström, J.; Richardson, K.; Lenton, T.M.; Folke, C.; Liverman, D.; Summerhayes, C.P.; Barnosky, A.D.; Cornell, S.E.; Crucifix, M.; et al. Trajectories of the Earth System in the Anthropocene. Proc. Natl. Acad. Sci. USA 2018. [CrossRef] [PubMed]

2. Steffen, W.; Richardson, K.; Rockström, J.; Cornell, S.E.; Fetzer, I.; Bennett, E.M.; Biggs, R.; Carpenter, S.R.; De Vries, W.; De Wit, C.A.; et al. Planetary boundaries: Guiding human development on a changing planet. Science 2015. [CrossRef] [PubMed]

3. Rodell, M.; Famiglietti, J.S.; Wiese, D.N.; Reager, J.T.; Beaudoing, H.K.; Landerer, F.W.; Lo, M.-H. Emerging trends in global freshwater availability. Nature 2018. [CrossRef] [PubMed]

4. Klein, R.J.T.; Adams, K.M.; Dzebo, A.; Davis, M.; Siebert, C.K. Advancing Climate Adaptation Practices and Solutions: Emerging Research Priorities; SEI Working Paper 2017-07; Stockholm Environment Institute: Stockholm, Sweden, 2017.

5. Ali, S.; Gugliemini, O.; Harber, S.; Harrison, A.; Houle, L.; Ivory, J.; Kersten, S.; Khan, R.; Kim, J.; LeBoa, C.; et al. Environmental and Social Change Drive the Explosive Emergence of Zika Virus in the Americas. PLoS Negl. Trop. Dis. 2017, 11, e0005135. [CrossRef]

6. Tjaden, N.B.; Suk, J.E.; Fischer, D.; Thomas, S.M.; Beierkuhnlein, C.; Semenza, J.C. Modelling the effects of global climate change on Chikungunya transmission in the 21 st century. Sci. Rep. 2017. [CrossRef]

7. Carlson, C.J.; Dougherty, E.R.; Getz, W. An Ecological Assessment of the Pandemic Threat of Zika Virus. PLoS Negl. Trop. Dis. 2016, 10, e0004968. [CrossRef]

8. Colón-González, F.J; Peres, C.A.; Steiner São Bernardo, C.; Hunter, P.R.; Lake, I.R. After the Epidemic: Zika Virus Projections for Latin America and the Caribbean. PLoS Negl. Trop. Dis. 2017, 11, e0006007. [CrossRef]

9. Zhao, C.; Liu, B.; Piao, S.; Wang, X.; Lobell, D.B.; Huan, Y.; Huang, M.; Yao, Y.; Bassu, S.; Ciais, P.; et al. Temperature Increase Reduces Global Yields of Major Crops in Four Independent Estimates. Proc. Natl. Acad. Sci. USA 2017. [CrossRef] 
10. Lenton, T.M. Early Warning of Climate Tipping Points. Nat. Clim. Change 2011, 1, 201. [CrossRef]

11. Giridharadas, A. Winners Take All; Penguin Random House: New York, NY, USA, 2018.

12. Kates, R.W.; Travis, W.R.; Wilbanks, T.J. Transformational Adaptation When Incremental Adaptations to Climate Change Are Insufficient. Proc. Natl. Acad. Sci. USA 2012, 201115521. [CrossRef]

13. Pelling, M.; O’Brien, K.; Matyas, D. Adaptation and Transformation. Clim. Change 2015, 133, $113-127$. [CrossRef]

14. Few, R.; Morchain, D.; Spear, D.; Mensah, A.; Bendapudi, R. Transformation, Adaptation and Development: Relating Concepts to Practice. Palgrave Commun. 2017, 3, 17092. [CrossRef]

15. Cardona, O.D.; van Aalst, M.K.; Birkmann, J.; Fordham, M.; McGregor, G.; Mechler, R. Determinants of risk: Exposure and vulnerability. In Managing the Risks of Extreme Events and Disasters to Advance Climate Change Adaptation; Field, C.B., Barros, V., Stocker, T.F., Eds.; Cambridge University Press: Cambridge, UK, 2012. [CrossRef]

16. Cutter, S.S.L.; Emrich, C.C.T.; Webb, J.J.J.; Morath, D. Social Vulnerability to Climate Variability Hazards: A Review of the Literature; Final Report to Oxfam America; University of South Carolina: Columbia, SC, USA, 2009.

17. Hochrainer-Stigler, S.; van der Velde, M.; Fritz, S.; Pflug, G. Remote Sensing Data for Managing Climate Risks: Index-Based Insurance and Growth Related Applications for Smallhold-Farmers in Ethiopia. Clim. Risk Manag. 2014, 6, 27-38. [CrossRef]

18. Lavell, A.; Oppenheimer, M.; Diop, C.; Hess, J.; Lempert, R.; Li, J.; Muir-Wood, R.; Myeong, S. Climate Change: New Dimensions in Disaster Risk, Exposure, Vulnerability, and Resilience. In Managing the Risks of Extreme Events and Disasters to Advance Climate Change Adaptation; 2011, Intergovernmental Panel on Climate Change Special Report on Managing the Risks of Extreme Events and Disasters to Advance Climate Change Adaptation; Cambridge University Press: Cambridge, UK, 2011. [CrossRef]

19. IPCC. Managing the Risks of Extreme Events and Disasters to Advance Climate Change Adaptation. Summary for Policymakers; Intergovernmental Panel on Climate Change Special Report on Managing the Risks of Extreme Events and Disasters to Advance Climate Change Adaptation; Cambridge University Press: Cambridge, UK, 2011.

20. UNWCDRR. Reconstructing After Disasters: Build Back Better. In UN World Conference on Disaster Risk Reduction; UNISDR: Sendai, Japan, 2015.

21. Mannakkara, S.; Wilkinson, S. Build Back Better Principles for Post-Disaster Structural Improvements. Struct. Surv. 2013, 31, 314-327. [CrossRef]

22. Wise, R.M.; Fazey, I.; Stafford Smith, M.; Park, S.E.; Eakin, H.C.; Archer Van Garderen, E.R.M.; Campbell, B. Reconceptualising adaptation to climate change as part of pathways of change and response. Glob. Environ. Change 2014, 28, 325-336. [CrossRef]

23. Terje Aven, O.R. An Evaluation of the Treatment of Risk and Uncertainties in the IPCC Reports on Climate Change. Risk Anal. 2014, 35, 701-712. [CrossRef] [PubMed]

24. O’Neill, B.C.; Kriegler, E.; Ebi, K.L.; Kemp-Benedict, E.; Riahi, K.; Rothman, D.S.; van Ruijven, B.J.; van Vuuren, D.P.; Birkmann, J.; Kok, K.; et al. The Roads Ahead: Narratives for Shared Socioeconomic Pathways Describing World Futures in the 21st Century. Glob. Environ. Change 2017, 42, 169-180. [CrossRef]

25. Popp, A.; Calvin, K.; Fujimori, S.; Havlik, P.; Humpenöder, F.; Stehfest, E.; Bodirsky, B.L.; Dietrich, J.P.; Doelmann, J.C.; Gusti, M.; et al. Land-use futures in the shared socio-economic pathways. Glob. Environ. Change 2017, 42, 331-345. [CrossRef]

26. Davenport, F.; Grace, K.; Funk, C.; Shukla, S. Child Health Outcomes in Sub-Saharan Africa: A Comparison of Changes in Climate and Socio-Economic Factors. Glob. Environ. Change 2017, 46, 72-87. [CrossRef]

27. Hinkel, J.; Lincke, D.; Vafeidis, A.T.; Perrette, M.; Nicholls, R.J.; Tol, R.S.J.; Marzeion, B.; Fettweis, X.; Ionescu, C.; Levermann, A. Coastal Flood Damage and Adaptation Costs under 21st Century Sea-Level Rise. Proc. Natl. Acad. Sci. USA 2014, 111, 3292-3297. [CrossRef]

28. Rockström, J.; Williams, J.; Daily, G.; Noble, A.; Matthews, N.; Gordon, L.; Wetterstrand, H.; DeClerck, F.; Shah, M.; Steduto, P. Sustainable Intensification of Agriculture for Human Prosperity and Global Sustainability. Ambio 2017, 46, 4-17. [CrossRef] [PubMed]

29. Bajželj, B.; Richards, K.S.; Allwood, J.M.; Smith, P.; Dennis, J.S.; Curmi, E.; Gilligan, C.A. Importance of Food-Demand Management for Climate Mitigation. Nat. Clim. Change 2014, 4, 924. [CrossRef]

30. Molotoks, A.; Kuhnert, M.; Dawson, T.; Smith, P. Global Hotspots of Conflict Risk between Food Security and Biodiversity Conservation. Land 2017, 6, 67. [CrossRef] 
31. Davis, K.F.; Gephart, J.A.; Emery, K.A.; Leach, A.M.; Galloway, J.N.; D'Odorico, P. Meeting Future Food Demand with Current Agricultural Resources. Glob. Environ. Change 2016, 39, 125-132. [CrossRef]

32. Tittonell, P.; Giller, K.E. When yield gaps are poverty traps: The paradigm of ecological intensification in African smallholder agriculture. Field Crop. Res. 2013. [CrossRef]

33. van Ittersum, M.K.; van Bussel, L.G.J.; Wolf, J.; Grassini, P.; van Wart, J.; Guilpart, N.; Claessens, L.; de Groot, H.; Wiebe, K.; Mason-D'Croz, D.; et al. Can sub-Saharan Africa feed itself? Proc. Natl. Acad. Sci. USA 2016. [CrossRef] [PubMed]

34. Bahrami, H.; De Kok, L.J.; Armstrong, R.; Fitzgerald, G.J.; Bourgault, M.; Henty, S.; Tausz, M.; Tausz-Posch, S. The Proportion of Nitrate in Leaf Nitrogen, but Not Changes in Root Growth, Are Associated with Decreased Grain Protein in Wheat under Elevated [CO2]. J. Plant Physiol. 2017. [CrossRef]

35. Loarie, S.R.; Duffy, P.B.; Hamilton, H.; Asner, G.P.; Field, C.B.; Ackerly, D.D. The Velocity of Climate Change. Nature 2009, 462, 1052. [CrossRef]

36. Zevenbergen, C.; Veerbeek, W.; Gersonius, B.; Van Herk, S. Challenges in urban flood management: Travelling across spatial and temporal scales. J. Flood Risk Manag. 2008. [CrossRef]

37. Coughlan De Perez, E.; Van Den Hurk, B.; Van Aalst, M.K.; Jongman, B.; Klose, T.; Suarez, P. Forecast-Based Financing: An Approach for Catalyzing Humanitarian Action Based on Extreme Weather and Climate Forecasts. Nat. Hazards Earth Syst. Sci. 2015, 15, 895-904. [CrossRef]

38. Cutter, S.L. The Landscape of Disaster Resilience Indicators in the USA. Nat. Hazards 2016, 80, 741-758. [CrossRef]

39. Lindsay, B.R. FEMA's Disaster Relief Fund: Overview and Selected Issues; Congressional Research Service Report; Congressional Research Service: Washington, DC, USA, 2014.

40. McCarthy, F.X. FEMA's Disaster Declaration Process: A Primer. In Federal Support for Domestic Disaster Assistance: Deployable Assets and Responders; Congressional Research Service: Washington, DC, USA, 2014.

41. Termeer, C.J.A.M.; Dewulf, A.; Biesbroek, G.R. Transformational change: Governance interventions for climate change adaptation from a continuous change perspective. J. Environ. Plan. Manag. 2017, 60, 558-576. [CrossRef]

42. Fan, X.; Fei, C.; McCarl, B. Adaptation: An Agricultural Challenge. Climate 2017, 5, 56. [CrossRef]

43. Schroth, G.; Läderach, P.; Martinez-Valle, A.I.; Bunn, C.; Jassogne, L. Vulnerability to Climate Change of Cocoa in West Africa: Patterns, Opportunities and Limits to Adaptation. Sci. Total. Environ. 2016. [CrossRef] [PubMed]

44. Nalau, J.; Handmer, J. When Is Transformation a Viable Policy Alternative? Environ. Sci. Policy 2015. [CrossRef]

45. Nobre, C.A.; Sampaio, G.; Borma, L.S.; Castilla-Rubio, J.C.; Silva, J.S.; Cardoso, M. Land-Use and Climate Change Risks in the Amazon and the Need of a Novel Sustainable Development Paradigm. Proc. Natl. Acad. Sci. USA 2016. [CrossRef]

46. Perkins-Kirkpatrick, S.E.; Gibson, P.B. Changes in Regional Heatwave Characteristics as a Function of Increasing Global Temperature. Sci. Rep. 2017. [CrossRef] [PubMed]

47. Abatzoglou, J.T.; Williams, A.P. Impact of Anthropogenic Climate Change on Wildfire across Western US Forests. Proc. Natl. Acad. Sci. USA 2016, 113, 11770-11775. [CrossRef] [PubMed]

48. Meixner, T.; Manning, A.H.; Stonestrom, D.A.; Allen, D.M.; Ajami, H.; Blasch, K.W.; Brookfield, A.E.; Castro, C.L.; Clark, J.F.; Gochis, D.J.; et al. Implications of Projected Climate Change for Groundwater Recharge in the Western United States. J. Hydrol. 2016, 534, 124-138. [CrossRef]

49. Tan, Y.; Zuo, A.; Hugo, G. Environment-related resettlement in China: A case study of the Ganzi Tibetan Autonomous Prefecture in Sichuan Province. Asian Pac. Migr. J. 2013. [CrossRef]

50. Below, T.B.; Mutabazi, K.D.; Kirschke, D.; Franke, C.; Sieber, S.; Siebert, R.; Tscherning, K. Can Farmers' Adaptation to Climate Change Be Explained by Socio-Economic Household-Level Variables? Glob. Environ. Change 2012, 22, 223-235. [CrossRef]

51. Tscharntke, T.; Clough, Y.; Wanger, T.C.; Jackson, L.; Motzke, I.; Perfecto, I.; Vandermeer, J.; Whitbread, A. Global food security, biodiversity conservation and the future of agricultural intensification. Biol. Conserv. 2012, 151, 53-59. [CrossRef] 
52. Maldonado, J.K.; Shearer, C.; Bronen, R.; Peterson, K.; Lazrus, H. The Impact of Climate Change on Tribal Communities in the US: Displacement, Relocation, and Human Rights. In Climate Change and Indigenous Peoples in the United States: Impacts, Experiences and Actions; Springer Science \& Business Media: Dordrecht, The Netherlands, 2014.

53. Matyas, D.; Pelling, M. Positioning Resilience for 2015: The Role of Resistance, Incremental Adjustment and Transformation in Disaster Risk Management Policy. Disasters 2015, 39, s1-s18. [CrossRef] [PubMed]

54. Central Bureau of Statistics. Profile of the Population of Central Java Supas 2015; BPS-Statistics Indonesia: Semarang, Indonesia, 2015.

55. Semarang Regency Planning. Semarang Regency Land Use Planning Spatial Dataset: 2011; Government of Indonesia: Jakarta, Indonesia, 2017.

56. Semarang City Planning. Semarang City Projected Land Use Planning Spatial Dataset 2031; MercyCorps Indonesia: Jakarta, Indonesia, 2017; p. 69.

57. JICA. E Detailed Design of Flood Control, Urban Drainage and Water Resources Development in Semarang in the Republic of Indonesia; CTI Engineering International Co., Ltd.: Tokyo, Japan; Pacific Consultants International: Osaka, Japan; Pasco International Inc.: Hong Kong, China, 2000.

58. Halsey, K.; Halsey, K.; Erhardt, M. Watershed Characterization and Flood Risk Reduction Assessment of the Garang River Basin in Semarang, Indonesia; Ecometrix: Polebank, MO, USA, 2018.

59. Scantlan, J.; Petryniak, O.; Tamang, C. Testing the Added Value of Market Incentives on Disaster Risk Reduction in Western Nepal; MercyCorps: London, UK, 2018.

60. Montaña, E.; Torres, L.M.; Abraham, E.M.; Torres, E.; Pastor, G. Los Espacios Invisibles. Subordinacion Marginalidad y Exculsion de Los Territories No Irrigados En Las Tierras Secas de Mendoza, Argentina. Región y Sociedad 2005, 17, 3-32.

61. Hurlbert, M.; Mussetta, P. Creating Resilient Water Governance for Irrigated Producers in Mendoza, Argentina. Environ. Sci. Policy 2016, 58, 83-94. [CrossRef]

62. Hurlbert, M.A.; Montana, E. Dimensions of Adaptive Water Governance and Drought in Argentina and Canada. J. Sustain. Dev. 2015, 8, 120. [CrossRef]

63. Hurlbert, M.A.; Diaz, H. Water Governance in Chile and Canada: A Comparison of Adaptive Characteristics. Ecol. Soc. 2013, 18. [CrossRef]

64. Hurlbert, M.A. Case Study Mendoza, Argentina. In Adaptive Governance of Disaster. Water GovernanceConcepts, Methods, and Practice. Adaptive Governance of Disaster: Drought and Flood in Rural Areas; Springer: Cham, Switzerland, 2018; pp. 169-190. [CrossRef]

65. Hurlbert, M. Learning, Participation, and Adaptation: Exploring Agri-Environmental Programmes. J. Environ. Plan. Manag. 2015, 58, 113-134. [CrossRef]

66. Hurlbert, M.; Gupta, J. The Adaptive Capacity of Institutions in Canada, Argentina, and Chile to Droughts and Floods. Reg. Environ. Change 2017, 17, 865-877. [CrossRef]

67. Foster, S.; Garduño, H. Groundwater-Resource Governance: Are Governments and Stakeholders Responding to the Challenge? Hydrogeol. J. 2013, 21, 317-320. [CrossRef]

68. Gregg, R.M.; Kershner, J.M.; Hansen, L.J.; Kershner, J.M.; Hansen, L.J. Strategies for Climate Change Adaptation: A Synthesis. In Encyclopedia of the Anthropocene; Elsevier Inc.: Amsterdam, The Netherlands, 2018. [CrossRef]

69. Tanner, T.; Lewis, D.; Wrathall, D.; Bronen, R.; Cradock-Henry, N.; Huq, S.; Lawless, C.; Nawrotzki, R.; Prasad, V.; Rahman, M.A.; et al. Livelihood resilience in the face of climate change. Nat. Clim. Change 2015. [CrossRef]

70. Marino, E. The Long History of Environmental Migration: Assessing Vulnerability Construction and Obstacles to Successful Relocation in Shishmaref, Alaska. Glob. Environ. Change 2012, 22, 374-381. [CrossRef]

71. Shearer, C. The political ecology of climate adaptation assistance: Alaska Natives, displacement, and relocation. J. Polity. Ecol. 2012. [CrossRef]

72. Thornton, T.F.; Comberti, C. Synergies and trade-offs between adaptation, mitigation and development. Clim. Change 2017. [CrossRef]

73. Bronen, R.; Chapin, F.S. Stuart Chapin. Adaptive Governance and Institutional Strategies for Climate-Induced Community Relocations in Alaska. Proc. Natl. Acad. Sci. USA 2013, 110, 9320-9325. [CrossRef] [PubMed] 
74. Kerwin, D. Creating a More Responsive and Seamless Refugee Protection System: The Scope, Promise and Limitations of US Temporary Protection Programs. J. Migr. Hum. Secur. 2014, 2, 44. [CrossRef]

75. Thomas, A.; Benjamin, L. Policies and mechanisms to address climate-induced migration and displacement in Pacific and Caribbean small island developing states. Int. J. Clim. Change Strateg. Manag. 2017. [CrossRef]

76. Farbotko, C.; Heather, L. The First Climate Refugees? Contesting Global Narratives of Climate Change in Tuvalu. Glob. Environ. Change 2012. [CrossRef]

77. McNamara, K.E. Cross-Border Migration with Dignity in Kiribati. Forced Migr. Rev. 2015, 62.

78. Lashley, J.G.; Warner, K. Evidence of Demand for Microinsurance for Coping and Adaptation to Weather Extremes in the Caribbean. Clim. Change 2015, 133, 101-112. [CrossRef]

79. Hallegatte, S.; Vogt-Schilb, A.; Bangalore, M.; Rozenberg, J. Unbreakable: Building the Resilience of the Poor in the Face of Natural Disasters; World Bank: Washington, DC, USA, 2017.

80. Venton, C.C. The Economics of Resilience to Drought. January 2018. Available online: https:/ / www.usaid.gov/sites/default/files/documents/1867/Kenya_Economics_of_Resilience_ Final_Jan_4_2018_-_BRANDED.pdf (accessed on 18 September 2018).

81. Banerjee, A.; Duflo, E.; Goldberg, N.; Karlan, D.; Osei, R.; Parienté, W.; Shapiro, J.; Thuysbaert, B.; Udry, C. A Multifaceted Program Causes Lasting Progress for the Very Poor: Evidence from Six Countries. Science 2015, 348, 1260799. [CrossRef] [PubMed]

82. Raza, W.; Poel, E. Impact and Spill-over Effects of an Asset Transfer Program on Malnutrition: Evidence from a Randomized Control Trial in Bangladesh. J. Health Econo. 2016, 62, 105-120. [CrossRef] [PubMed]

83. Davies, M.; Béné, C.; Arnall, A.; Tanner, T.; Newsham, A.; Coirolo, C. Promoting Resilient Livelihoods through Adaptive Social Protection: Lessons from 124 Programmes in South Asia. Dev. Policy Rev. 2013, 31, 27-58. [CrossRef]

84. Marshall, N.; Park, S.; Adger, W.N.; Brown, K.; Howden, S. Transformational Capacity and the Influence of Place and Identity. Environ. Res. Lett. 2012, 7, 034022. [CrossRef]

85. Gorddard, R.; Colloff, M.J.; Wise, R.M.; Ware, D.; Dunlop, M. Values, Rules and Knowledge: Adaptation as Change in the Decision Context. Environ. Sci. Policy 2016, 57, 60-69. [CrossRef]

86. Zetter, R. Legal and Normative Frameworks. Forced Migr. Rev. 2008, 31, 62-63.

87. Hugo, G.J. Lessons from Past Forced Resettlement for Climate Change Migration. In Migration and Climate Change; UNESCO Publishing: Paris, France; Cambridge University Press: Cambridge, UK, 2011.

88. Amaru, S.; Chhetri, N.B. Climate Adaptation: Institutional Response to Environmental Constraints, and the Need for Increased Flexibility, Participation, and Integration of Approaches. Appl. Geogr. 2013, 39, 128-139. [CrossRef]

89. Challinor, A.J.; Adger, W.N.; Benton, T.G. Climate Risks across Borders and Scales. Nat. Clim. Change 2017, 7, 621-623. [CrossRef]

90. Kaime, T. Cultural Legitimacy and Intenratioal Law and Policy on Climate Change: An Introduction. In International Climate Change Law and Policy; Kaime, T., Ed.; Routledge: Abingdon, UK, 2014; pp. 1-6.

91. Chu, E.; Anguelovski, I.; Carmin, J. Inclusive Approaches to Urban Climate Adaptation Planning and Implementation in the Global South. Clim. Policy 2016, 16, 372-392. [CrossRef]

92. Berkhout, F.; Hertin, J.; Gann, D.M. Learning to Adapt: Organisational Adaptation to Climate Change Impacts. Clim. Change 2006, 78, 135-156. [CrossRef]

93. Sharpe, J. Understanding and unlocking transformative learning as a method for enabling behaviour change for adaptation and resilience to disaster threats. Int. J. Disaster Risk Reduct. 2016. [CrossRef]

94. Hallegatte, S. Strategies to Adapt to an Uncertain Climate. Glob. Environ. Change 2009, 19, 240-247. [CrossRef]

95. Sharma-Wallace, L.; Velarde, S.J.; Wreford, A. Adaptive governance good practice: Show me the evidence! J. Environ. Manag. 2018, 222, 174-184. [CrossRef] [PubMed]

96. Van Buuren, A.; Driessen, P.; Teisman, G.; van Rijswick, M. Toward legitimate governance strategies for climate adaptation in the Netherlands: Combining insights from a legal, planning, and network perspective. Reg. Environ. Change 2014. [CrossRef]

97. Gersonius, B.; Ashley, R.; Pathirana, A.; Zevenbergen, C. Climate Change Uncertainty: Building Flexibility into Water and Flood Risk Infrastructure. Clim. Change 2013, 116, 411-423. [CrossRef]

98. Gersonius, B.; van Buuren, A.; Zethof, M.; Kelder, E. Resilient Flood Risk Strategies: Institutional Preconditions for Implementation. Ecol. Soc. 2016, 21, 21. [CrossRef] 
99. Pahl-Wostl, C. A Conceptual Framework for Analysing Adaptive Capacity and Multi-Level Learning Processes in Resource Governance Regimes. Glob. Environ. Change 2009, 19, 354. [CrossRef]

100. Radhakrishnan, M.; Pathirana, A.; Ashley, R.; Zevenbergen, C. Structuring Climate Adaptation through Multiple Perspectives: Framework and Case Study on Flood Risk Management. Water 2017. [CrossRef]

101. Connolly-Boutin, L.; Smit, B. Climate Change, Food Security, and Livelihoods in Sub-Saharan Africa. Reg. Environ. Change 2016. [CrossRef]

102. Jackson, L.E.; Pulleman, M.M.; Brussaard, L.; Bawa, K.S.; Brown, G.G.; Cardoso, I.M.; de Ruiter, P.C.; García-Barrios, L.; Hollander, A.D.; Lavelle, P.; et al. Social-Ecological and Regional Adaptation of Agrobiodiversity Management across a Global Set of Research Regions. Glob. Environ. Change 2012, 22, 623-639. [CrossRef]

103. Lipper, L.; Thornton, P.; Campbell, B.M.; Baedeker, T.; Braimoh, A.; Bwalya, M.; Caron, P.; Cattaneo, A.; Garrity, D.; Henry, K.; et al. Climate-Smart Agriculture for Food Security. Nat. Clim. Change 2014, 4, 1068. [CrossRef]

104. Kousky, C. Managing Shoreline Retreat: A US Perspective. Clim. Change 2014, 124, 9-20. [CrossRef]

105. Crickette, G.; Demian, R.; Fox, C.; Hach, J.; Makomaski, J.; Mazumdar, R.; McGuire, R. Exploring Risk Appetite and Tolerance; RIMS Executive Report; Risk Management Society: New York, NY, USA, 2012.

106. Dow, K.; Berkhout, F.; Preston, B.L. Limits to Adaptation to Climate Change: A Risk Approach. Curr. Opin. Environ. Sustain. 2013, 5, 384-391. [CrossRef]

107. Preston, B.L.; Dow, K.; Berkhout, F. The climate adaptation frontier. Sustainability 2013. [CrossRef]

(C) 2019 by the authors. Licensee MDPI, Basel, Switzerland. This article is an open access article distributed under the terms and conditions of the Creative Commons Attribution (CC BY) license (http:/ / creativecommons.org/licenses/by/4.0/). 